UDK: 316.647 .6

Primljeno: 14. 9. 2020.

Prihvaćeno za štampu: 23. 11. 2020.

Dr. sc. Dijana Sulejmanović, viši asistent

Univerzitet u Bihaću

Islamski pedagoški fakultet

E-mail:dijana.sulejmanovi@@itf.unbi.ba

\title{
SKRIVENI IZA GOMILE
}

\section{Sažetak}

Konformizam se obicno posmatra kao oblik socijalnog utjecaja gdje se pojedinac prilagođava grupi, odnosno, gdje pojedinac mijenja svoje stavove $i$ ponašanja $i$ prilagođava ih stavovima i ponašanjima grupe kojoj pripada ili kojoj želi da pripada. Cilj ovog rada jeste naglašavanje potrebe da se konformiranje grupi raqlikuje od pokornosti grupi. Konformiranje grupi prati želja da se bude što sličniji većini, da se prisvoje grupne vrijednosti ili saznanja, pri čemu pojedinac sam bira da li ce se prikloniti grupi ili vecini.

Ključne riječi: konformizam, konformiranje, socijalni utjecaj, socijalna grupa

\section{Uvod}

Apatičnost i ravnodušnost odavno su postali sastavnim dijelom života u velikim gradovima pa pojedinac, iako član brojnih socijalnih grupa, ostaje neshvaćeni kamijevski 'stranac' ukoliko svojim ponašanjem odstupa od prosječnosti i uniformnosti. Prema takvom neprosječnom pojedincu, samcu u stadu kako ga opisuju Pronin i drugi (2007), društvo nije podržavajuće. Baš kao što životinja prati čopor da bi ostala zaštićena gomilom, tako se i čovjek okružuje udobnošću tuđeg mišljenja da bi se zaštitio od realne, ili pak imaginarne, opasnosti. I bilo da tu gomilu predvodi ovan ili vuk, konformizam se nerijetko koristi kao opravdanje za brojne asocijalne i amoralne akcije poduzete od strane čovjeka. Ovaj socijalni fenomen, kao podvrsta socijalnog 
utjecaja, odnosno, utjecaja koji većina ili grupa ima na manjinu ili pojedinca, očituje se na različite načine, u svakodnevnim situacijama i u socijalnim zajednicama širom svijeta.

Istraživanja socijalnog utjecaja grupe na pojedinca i njegovog odgovora na taj utjecaj, jedan su od najprisutnijih istraživačkih problema $u$ povijesti socijalne psihologije.

\section{Konformizam ili prepuštanje drugima}

Socijalni utjecaj pokazuje kako na naše ponašanje utječu socijalna sredina i drugi ljudi. Prema definiciji, o socijalnom utjecaju govorimo kada izvor učestvuje u ponašanju koje uzrokuje da se meta ponaša drugačije nego što bi se inače ponašala (DeLamater i Myers, 2011). Izvor je, pritom, osoba koja vrši socijalni utjecaj, a meta je osoba na koju se vrši socijalni utjecaj. Drugim riječima, izvor je grupa, a meta je pojedinac koji želi postati ili ostati član te grupe.

Deutsch i Gerard (1955) konformizam kao fenomen objašnjavaju jednim od dva moguća razloga. Prvi razlog je tzv. normativni socijalni utjecaj, a drugi je tzv. informacijski socijalni utjecaj. Willis (1963) pored normativnog i informacijskog, navodi još i tzv. "udvorički" konformizam koji postoji onda kada pojedinac želi da bude prihvaćen $\mathrm{i}$ priznat od strane drugih, iako ne postoji socijalni pritisak. Ovaj se oblik konformizma obično javlja u situacijama hijerarhijske strukture i zavisnosti pojedinca (tzv. "karijerizam”).

Ponašanje koje se smatra prihvatljivim u jednoj socijalnoj grupi, može biti neprihvaćeno i nedopustivo u drugoj, a socijalne norme služe kao putokaz kako se treba ponašati u određenoj prilici da bi se dobila naklonost ili prihvatanje drugih. Socijalne norme zapravo određuju ponašanje koje je socijalno prihvatljivo unutar neke socijalne grupe, a nepoštivanje pravila može dovesti do teških kazni, uključujući i isključenje iz socijalne grupe. Vrijednost postojanja socijalnih normi jeste $u$ tome što su to pravila prihvaćenog i očekivanog ponašanja $u$ određenoj socijalnoj situaciji, koja propisuju šta jeste odgovarajuće ponašanje, opisuju kako se većina ljudi ponaša i olakšavaju komunikaciju u grupi jer ljudi znaju što mogu očekivati jedni od drugih. Tzv. normativni konformizam, kao odgovor pojedinca na izloženost socijalnom utjecaju, odnosno utjecaju grupe i grupnih pravila i normi, 
podrazumijeva neposredni socijalni pritisak, odnosno postojanje manifestne socijalne norme i vrijednosti u okviru kojih će određeni oblici ponašanja biti nagrađeni, a drugi kažnjeni. "Kada si u Rimu, ponašaj se kao Rimljanin" postalo je univerzalno pravilo kako treba reagovati u situaciji koja je novost za pojedinca i na koju nije pripremljen. Ovakav vid konformizma posebno je prisutan u kolektivističkim društvima, gdje je zajednički odgovor na svakodnevne situacije uobičajen i socijalno poželjan.

Slijeđenje kôda grupe, bez kritičke provjere ispravnosti onog što grupa promovira kao vrijednost, može voditi ka rastu pojedinca onda kada je grupa pozitivna, orijentisana ka prosocijalnom ponašanju i razvijanju dobra. Kada, međutim, grupa promovira, potiče i podržava ponašanja koja ne doprinose općem dobru, usvajanje vrijednosti ovakve grupe može rezultirati ličnim nezadovoljstvom, osjećanju poraženosti i bespomoćnosti pojedinca koji slijedi tu grupu. Racionalnost djelovanja obično počiva na društvenom ugovoru o prihvatljivom i poželjnom, ali kada su prisutne kognitivne distorzije ili iskrivljenosti u mišljenju, racionalno ponašanje zamijenjeno je iracionalnim, a grupa će i dalje ustrajati na neophodnosti istog u cilju zaštite kako same grupe, tako i svih pojedinaca koji čine grupu.

Odnos između (i)racionalnosti uvjerenja i konformističkog odgovora pojedinca na izloženost socijalom utjecaju grupe ne može se posmatrati bez uključivanja mjere samopoštovanja kao ličnog motiva pojedinca da prati grupu. Greiger (1975) još navodi da nisko samopoštovanje počiva na iracionalnim uvjerenjima pojedinca, što u okvirima moderne Racionalno-emotivno bihejvioralne teorije (REBT) (Ellis, 1994) možemo objasniti viđenjem sebe, drugih i svijeta oko sebe izrazito negativistički, a što obično nalazimo kod osoba koje imaju različite kognitivne distorzije, odnosno koje netačno, pogrešno opažaju realnost i imaju nerealnu sliku o sopstvenoj (ne)vrijednosti. Pod iracionalnim uvjerenjima se u REBT pristupu podrazumijevaju kognitivni procesi koji obuhvataju rigidne evaluacije, dogmatske, nerealistične i nelogične misli, a koje su disfunkcionalne u odnosu na vrijednosti i ciljeve pojedinca (Marić, 2000; Vukosavljević-Gvozden, 2009). 


\section{Da li je konformizam poslušnost ili pokornost utjecaju drugih?}

Premda se u literaturi navodi kao rezultat grupnog pritiska, a ne samo grupnog utjecaja, konformizam nije sinonim za poslušnost autoritetu većine, odnosno grupe. On, neupitno, predstavlja oblik pokornosti pojedinca utjecaju grupe, ali sile koje pokreću ovaj odgovor na specifičan stimulus koji dolazi od većine ne treba posmatrati nezavisno od sklonosti samog pojedinca da se prikloni većini - posebno onda kada se to od njega ne zahtijeva. Pionirski eksperimenti koje su izvodili Solomon Asch (1956) i Stanley Milgram (1963) proizveli su povoljnu istraživačku klimu da se pažljivije pristupi ispitivanju djelovanja utjecaja grupe na pojedinca. Kao varijante pokornosti, tj. spremnosti pojedinca da promijeni svoje ponašanje ili uvjerenja pod utjecajem nekih vanjskih faktora, čak i u situacijama kada ne želi tu promjenu, konformizam bi se mogao opisati kao sklonost pojedinca da slijedi grupu - iako grupa to od njega ne zahtijeva, ali potkrepljuje takvo ponašanje. Stavljanjem znaka jednakosti između konformizma i poslušnosti grupi i dalje govorimo o pokornosti kao nadređenoj kategoriji, ali poslušnost počiva na uvažavanju autoriteta, onome čega kod konformizma nema. Što je grupa veća, konformizam će biti veći govoreći o normativnom konformizmu; što je situacija nepoznatija, a grupa sigurnija u ono što radi, konformizam će biti veći - govoreći o informacijskom konformizmu. Zašto je ovo važno naglasiti i stalno insistirati na razlikovanju ovih pojmova? Ako bismo poistovjetili fenomen poslušnosti s konformističkim odgovorom pojedinca na socijalni utjecaj, očekivalo bi se da su isti prediktori oba ova fenomena, odnosno da poznavanjem determinanti konformističkog odgovora možemo zaključivati i o spremnosti pojedinca da pokaže poslušnost u situacijama koje se protive njegovim moralnim načelima $i$ vrijednostima. Ovo bi značilo da su svi oni koji su činili stravične zločine pod naredbom pretpostavljenog - jednostavno konformni i da se od svakog konformistički orijentisanog pojedinca, ili grupe, treba očekivati apsolutna poslušnost. Polazeći od konformizma kao dokazane karakteristike kolektivističkih društava, a istovremeno fenomena koji je nepoželjan u individualistički orijentisanim kulturama, ovo bi značilo da će zločine iz poslušnosti izvršiti samo oni pojedinci koji dolaze iz kolektivističkih društava. I najmanje poznavanje povijesti posljednjih nekoliko decenija pokazalo bi nelogičnost i, važnije, neutemeljenost ovakve pretpostavke. Zato je važno naglašavati različitost fenomena 
konformizma od fenomena poslušnosti, uz stalno usmjeravanje istraživačkog interesovanja u smjeru otkrivanja determinanti i jednog $i$ drugog oblika odgovora pojedinca na djelovanje drugih, i pojedinaca $i$ grupa.

\section{Literatura}

1. Asch, S. (1956) Studies of Independence and Conformity: A Minority of One Against a Unanimos Majority. Psychological Monographs: General and Applied, 70 (9), 1-70.

2. DeLamater, J. D. \& Myers, D. J. (2011) Social Psychology. Wadsworth: Cengage Learning.

3. Deutsch, M. \& Gerard, H. B. (1955) A study of normative and informational social influences upon individual judgment . J. abnorm. soc. Psychol. 51, 629-636 .

4. Ellis, A. (1994). Reason and emotion in psychotherapy (2nd Ed.). Secaucus, NJ: Birch Lane.

5. Greiger, R. (1975) Self-concept, self-esteem and rational-emotive theory: A brief perspective. Rational Living, 10, 13-17.

6. Marić, Z. (2000) Priručnik za primarni kurs iz Racionalno-Emotivno Bihejvioralne Terapije.

7. Milgram, Stanley (1963) "Behavioral Study of Obedience". Journal of Abnormal and Social Psychology. 67 (4): 371-8.

8. Pronin, E., Berger, J. \& Molouki, S. (2007) Alone in a Crowd of Sheep: Asymmetric Perceptions of Conformity and Their Roots in an Introspection Illusion. Journal of Personality and Social Psychology, 92(4), 585-595.

9. Vukosavljević-Gvozden, T. (2009) Racionalno-emotivna bihejvioralna terapija. Beograd: Kreativni centar.

10. Willis, R. H. (1963) Two Dimensions of Conformity-Nonconformity. Sociometry, $26 \quad$ (4), 499-513. 
dr. sci. Dijana Sulejmanović, senior assistant

University of Bihać

Islamic Pedagogical Faculty

Email:dijana.sulejmanovic@ipf.unbi.ba

\section{HIDDEN BEHIND THE CROWD}

\section{Summary}

Conformism is usually seen as a form of social influence where the individual adapts to the group, that is, where the individual changes his attitudes and behaviors and adapts them to the attitudes and behaviors of the group to which he belongs or to which he wants to belong. The aim of this paper is to emphasize the need to distinguish group conformity from group obedience. Conforming a group is accompanied by a desire to be as similar as possible to the

majority, to appropriate group values or knowledge, with the individual choosing whether to join the group or the majority.

Key words: conformism, conforming, social influence, social group 


\section{الدكتورة المعيدة ديانا سليمانوفيتش دانش

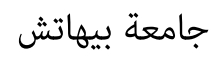 كلية التربية الإسلامية} E-mail: dijana.sulejmanovic@ipf.unbi.ba

\section{المختبئون خلف الحشود}

\section{الخلاصة}

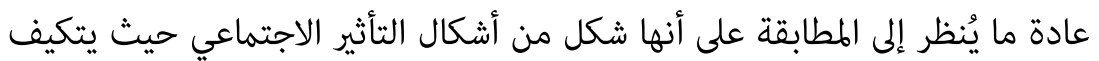

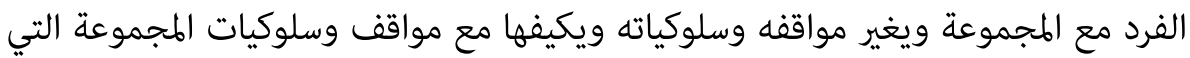

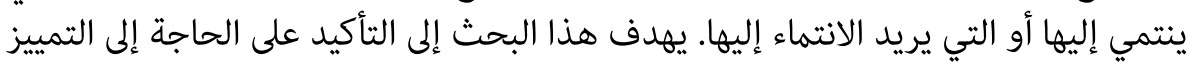

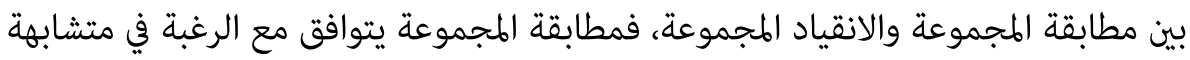

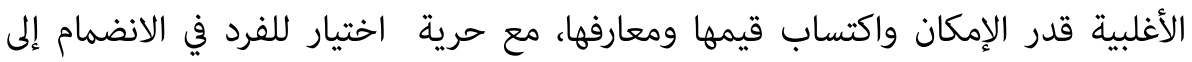
المجموعة أو إلى الأغلبية فيها.

الكلمات المفتاحية: المطابقة، التطابق، التأثير الاجتماعي، المجموعة الاجتماعية. 